\title{
Pelatihan Sablon bagi Karang Taruna dalam Menciptakan Peluang Bisnis
}

\author{
Ima Mulyawati ${ }^{*}$ dan Silvy Mei Pradita $^{1}$ \\ ${ }^{1,2}$ Universitas Muhammadiyah Prof. DR. HAMKA Jl. Tanah Merdeka, Jakarta Timur, Indonesia \\ Email: Ima.mulyawati@uhamka.ac.id
}

\begin{abstract}
Abstrak
PKM pengabdian masyarakat melalui pelatihan sablon bagi karang taruna dalam menciptakan peluang bisnis di Rt 11 Rw 05 Kecamatan Ciracas dan Pengurus Cabang Aisyiyah Ciracas Jakarta Timur. Pelatihan ini dilakukan di tempat pelaksanaan pelatihan dilakukan di Jalan Gebras Kecamatan Ciracas Jakarta Timur dengan jumlah peserta 30 orang. Adapun target luaran yang diharapkan dari pengabdian ini adalah 1) jasa berupa workshop dan latihan kewiraushaan dan latihan kreativitas sablon bagi pemuda karang taruna, 2) $80 \%$ peserta memiliki motivasi besar untuk kreatif dalam berwirausaha dalam bentuk mensablon, 3) baju hasil pelatihan sablon yang memiliki nilai jual, 4) memiliki panduan dan tutorial mensablon dan memasarkan barang bernilai jual. Rancangan kegiatan meliputi tahap persiapan, tahap pelaksananaan pelatihan yaitu metode ceramah/persentasi, metode praktik langsung, metode tanya jawab, partisipasi mitra dan evaluasi. Hasil yang dicapai dari kegiatan pengabdian masyarakat adalah 1) pelatihan sablon berisi materi teknologi tepat guna yang dibutuhkan masyarakat umum, 2) diperlukan koordinasi antara stakeholder yang berkompeten baik antara masyarakat, pemerintah maupun akademisi dalam memberi ketrampilan yang sejenis yang bermanfaat ke depannya agar membuka keterampilan berwirausaha bagi pemuda karang taruna.
\end{abstract}

Kata kunci: Sablon, karang taruna, bisnis, PKM

\begin{abstract}
PKM community service through screen printing training for youth cadets in creating business opportunities in Rt 11 Rw 05 Ciracas Subdistrict and Management of Aisyiyah Ciracas Branch East Jakarta. This training was conducted at the place where the training was conducted at Jalan Gebras, Ciracas Sub-District, East Jakarta, with 30 participants. The expected outputs of this service are 1) services in the form of entrepreneurial workshops and exercises and screenprinting creativity training for youth youth, 2) 80\% of participants have a great motivation to be creative in entrepreneurship in the form of mensablon, 3) clothes made by screen printing training selling points, 4) have a mensablon guide and tutorial and sell goods of sale value. The design of the activity includes the preparation stage, the training implementation phase, namely lecture / presentation method, direct practice method, question and answer method, partner participation and evaluation. The results achieved from the community service activities are 1) screen printing training with the materials of appropriate technology needed by the general public, 2) coordination between competent stakeholders between the community, government and academics in providing similar useful skills in the future to open entrepreneurship skills for youth in Karang Taruna.
\end{abstract}

Keywords: Screen Printing, Sablon, youth, business, PKM

Format Sitasi: Mulyawati, I. \& Pradita, S.M. (2018). Pelatihan Sablon bagi Karang Taruna dalam Menciptakan Peluang Bisnis. Jurnal SOLMA, 02(2), 299-308. Doi: http://dx.doi.org/10.29405/solma.v7i2.1726

Diterima: 7 Juli 2018 | Revisi: 4 September 2018 | Dipublikasikan: 30 Oktober 2018.

\section{PENDAHULUAN}

Pesatnya perkembangan dunia fashion yang melanda anak muda khususnya wilayah DKI Jakarta menjadikan kebutuhan akan ketersediaan fashion semakin meningkat. Menurut Hendariningrum dan Susilo (2008), fashion bisa menjadi etalase kecil tentang diri 
seseorang bagi orang lain yang merupakan penilaian awal seseorang dalam berbusana. Berbusana tidak akan pernah lepas dari perhatian setiap individu karena akan menampilkan karakter setiap individu (Lestari, 2014). Hanya dengan mengenakan jenis pakaian tertentu maka orang lain akan menilai kepribadian dan citra dirinya. Karena fashion bisa menampilkan sesuatu yang tidak terucap secara verbal maka fashion seringkali digunakan sebagai identitas personal dari individu yang bersangkutan (Trisnawati, 2011).

Pesatnya perkembangan dunia fashion terutama yang sedang melanda anak muda DKI Jakarta khususnya perempuan yang menjadikan fashion sebagai kebutuhan tersendiri dalam berpenampilan sehari-hari. Hal ini mendorong maraknya pusat berbelanjaan dan distro yang berkembang begitu pesat. Selain itu, toko dipinggir jalan tidak ketinggalan pula menawarkan gaya fashion yang kreatif dan inovatif dengan ciri khas masing-masing. Hal ini membuat peluang fashion yang semakin meningkat.

Namun melihat di lapangan permasalahan tenaga kerja di Indonesia akhir-akhir ini semakin kompleks. Hal ini dapat diamati dari jumlah pengangguran yang terus meningkat dan terbatasnya lapangan pekerjaan yang tersedia saat ini. Pengangguran yang terjadi merupakan lulusan jenjang pendidikan SMA dan Perguruan Tinggi dari tahun ke tahun populasi pengangguran terdidik di Indonesia bukannya malah surut tetapi bertambah, mengingat pertumbuhan anak usia sekolah dan para pencari kerja dari tahun ke tahun semakin meningkat.

Pengangguran masih menjadi permasalahan tersendiri bagi Bangsa Indonesia. Sulitnya mencari lapangan pekerjaan tidak sebanding dengan jumlah lulusan yang ada. Lapangan pekerjaan tidak tumbuh bertumbuhkembang secara cepat dan sulit bertambah jumlahnya secara signifikant. Hal ini mendorong pemerintah untuk membuka lapangan kerja bagi masyarakat seluas-luasnya dan mendorong masyarakat untuk berwirausaha. Hal ini tidak semudah mengembalikan telapak tangan. Jumlah pengangguran di negeri ini tidak berkurang drastis dan minat berwirausaha di Indonesia masih rendah. Jumlah wirausaha di Indonesia baru Indonesia baru punya 3,3 persen sangat jauh dibandingkan dengan Negara lain sepertu Singapura 7 persen, Malaysia 5 persen sangat jauh disbanding dengan Negara lain (Manafe, 2017).

Kondisi ini didukung pula pada kenyataan bahwa sebagian besar lulusan Perguruan Tinggi adalah sebagai pencari kerja daripada menciptakan lapangan pekerjaan. Hal ini bisa jadi disebabkan karena sistem pembelajaran yang diterapkan di berbagai perguruan tinggi 
saat ini lebih berfokus pada bagaimana menyiapkan para mahasiswa yang cepat lulus dan mendapatkan pekerjaan, bukannya lulusan yang siap menciptakan lapangan pekerjaan.

Kewirausahaan merupakan kemampuan kreatif dan inovatif, jeli melihat peluang dan selalu terbuka untuk setiap masukan dan perubahan yang positif yang mampu membawa bisnis terus bertumbuh serta memiliki nilai (Sarangih, 2017). Menurut Sumardi (2007) menjelaskan bahwa wirausahawan (entrepreneur) seseorang yang berani mengambil resiko dan ketidakpastian untuk menciptakan sebuah bisnis yang diharapkan dengan cara membuka kesempatan. Dewasa ini, banyak kesempatan seseorang untuk berwirausaha bagi seseorang yang jeli untuk melihat peluang salahsatunya bisnis usaha sablon. Karier kewirausahaan dapat mendukung kesejahteraan masyarakat yaitu menghasilkan imbalan finansial yang nyata (Agustina \& Sularto, 2011).

Karang taruna yang ada di RT 03 RW 10 mengalami gambaran seperti yang dijelaskan di atas, mengalami problematika yakni banyaknya pemuda-pemuda yang pengangguran dan tidak bersekolah karena faktor ekonomi rendah dan begitu pula dengan Aisyiyah yang kurangnya pemasukan dana untuk memajukan amal usaha Muhammadiyah khususnya pendidikan. Hal ini sesuai dengan wawancara tim pelaksana kepada ketua RT Tety Juhriah bahwa sangat membutuhkan diadakan pelatihan Sablon guna pemuda dan pemudi tidak menjadi anak yang terlantar dan menjadi anak nakal karena derasnya arus globalisasi pergaulan yang negatif.

Cetak sablon pada umumnya sudah dikenal oleh masyarakat namun hanya sebagian kecil saja yang mengetahui, mengenal, dan menguasai keterampilan ini. Cetak sablon ini merupakan jenis keterampilan praktis yang diperoleh melalui pengalaman dan sangat jarang orang menekuni bidang ini merupakan lulusan jenjang pendidikan khusus. Perkembangan cetak sablon yang sering disebut screen printing sejalan dengan perkembangan dunia fashion dan dunia percetakan dewasa ini. Untuk berwirausaha cetak sablon ini perlu memiliki pengetahuan, pemahaman dan keterampilan teknis dan estetis.

Problematika di atas, dapat dicegah sedini mungkin dan tidak terjadi semakin komplek. Universitas Muhammadiyah Prof. Dr. Hamka sebagai solusi dari permasalahan ini, tim pengabdian masyarakat bermaksud mengadakan kegiatan pengabdian masyarakat berupa pelatihan Sablon dalam peluang bisnis dan sekaligus menciptakan kreativitas serta diharapkan mampu bekerja dengan baik dilihat dari segi ilmu maupun teknis lapangan dan sebisa mungkin seorang pemuda taruna dituntut untuk berpikir secara kreatif terhadap peluang bisnis yang ada di masyarakat dan berani mencoba untuk memulai usaha. 


\section{MASALAH}

Berdasarkan uraian pada analisis situasi di atas, dapat ditarik pokok yang dihadapi oleh mitra pada Karang taruna Rt. 11 Rw. 05 Kecamatan Ciracas dan Pengurus cabang Aisyiyah Ciracas Jakarta Timur, meliputi beberapa permasalahan di antaranya: 1) banyaknya pemuda taruna putus sekolah, 2) banyaknya pemuda taruna yang tidak memiliki aktivitas, 3) kurangnya pemahaman diri betapa pentingnya berwirausaha, 4) kurang memiliki motivasi dan tidak memiliki semangat serta keinginan untuk berusaha sendiri, 5) rendahnya intensi berwirausaha pada pemuda taruna karena ragu-ragu dan takut gagal sehingga mereka tidak siap menghadapi rintangan yang ada, 6) tidak memiliki modal, 7) tidak memiliki kreativitas dan takut untuk memulai.

Berikut adalah solusi yang ditawarkan bagi mitra PKM adalah melakukan workshop dan pelatihan mengenai sablon dalam memberikan peluang bisnis dalam menumbuhkan jiwa kewirausahaan yang mudah dan menarik, diantaranya: 1) memberikan pengetahuan kepada pemuda taruna dan Aisyiyah pentingnya berwirausaha untuk masa depan, 2) memandirikan pemuda taruna dan Aisyiyah agar kelak mereka memiliki keterampilan yang dapat digunakan untuk mencari penghasilan, 3) menumbuhkan pemuda taruna dan Aisyiyah agar mempunyai semangat kreativitas dalam mengolah sablon menjadi produk yang memiliki daya jual, 4) perlu pelatihan khusus mengenai sablon.

Adapun target luaran yang diharapkan dari pelaksanaan pengabdian masyarakat ini adalah. 1) meningkatkan pengetahuan kepada pemuda taruna dan Aisyiyah tentang pentingnya berwirausaha untuk masa depan, 2) memandirikan besar keterampilan yang dimiliki dalam mencari penghasilan, 3) meningkatkan semangat kreativitas dalam mengolah sablon menjadi produk yang memiliki daya jual, 4) perlu pelatihan khusus mengenai sablon.

\section{METODE PELAKSANAAN}

Berdasarkan permasalahan tersebut, maka solusi yang ditawarkan adalah melakukan pelatihan sablon sebagai program usaha bagi karang taruna di karang taruna Rt. $011 \mathrm{Rw}$. 005 kecamatan ciracas dan pengurus cabang aisyah ciracas Jakarta Timur. Berikut adalah uraiannya:

1. Tahap pertama adalah tahap persiapan meliputi mengidentifikasi pemuda taruna di RT 03 RW 10 yang tidak bersekolah dan pengurus Aisyiyah majelis Ekonomi yang dikategorikan ingin berwirausaha, melakukan analisis terhadap data tersebut, kemudian mengkonsultasikan kepada ahli dalam bidang kewirausahaan, melakukan 
konsultasi dengan Dekan, wakil Dekan, Kaprodi serta pihak-pihak yang terkait mengenai kegiatan ini termasuk LPPM Uhamka.

2. Tahap kedua adalah tahap pelaksanaan workshop yaitu dengan melaksanakan TOT (Tutor OF Trainer) bagi Instruktur yang didampingi oleh ketua koordinator tim sablon yang telah diberi pelatihan dan petunjuk.

3. Tahap ketiga adalah metode pendekatan workshop diantaranya metode ceramah/persentasi, metode praktik langsung, metode tanya jawab dan simulasi. Metode ceramah ini bertujuan untuk mendengarkan tentang kewirausahaan. Metode praktik langsung ini bertujuan untuk memberikan kesempatan untuk belajar langsung mengenai langkah dasar dalam membuat sablon. Dengan konsep learning by doing (belajar sambil mempraktekkan), pengetahuan dan ketrampilan mengenai hal tersebut dan akan memperoleh hasil yang optimal dan memuaskan disertai praktek penyablonan untuk siap dijual. Metode tanya jawab ini sangat penting bagi peserta baik di saat menerima penjelasan tentang penyablonan maupun praktik langsung penyablonan. Metode ini memungkinkan bagi peserta pelatihan sablon untuk menggali pengetahuan sebanyak-banyaknya bagaimana menyablon yang baik sehingga produk hasil sablon siap untuk dijual.

4. Tahap keempat adalah partisipasi mitra. Partisipasi mitra dalam kegiatan pelatihan ini adalah dalam mengkoordinasikan pelaksanaan kegiatan, mulai dari mengundang dan mengumpulkan calon peserta pelatihan, mengkoordinasikan waktu pelaksanaan, sampai pada penyedian sarana dan prasarana pelatihan.

5. Tahap kelima adalah evaluasi. Evaluasi dilakukan terkait dengan kegiatan yang telah dilakukan berupa angket tanggapan peserta pelatihan terhadap praktik pelaksanaan PKM pelatihan penyablonan seperti: peningkatan keterampilan dalam hal penyablonan, keuntungan yang didapatkan setelah produksi dan bagaimana perputaran anggaran untuk kelanjutan berwirausaha.

\section{PEMBAHASAN}

Pengabdian Kepada Masyarakat bertujuan untuk memberikan bantuan keterampilan menyablon kepada para pemuda karang taruna di RT 11 RW 05 dan penguruas Aisyiyah cabang Ciracas Jakarta Timur. Jenis pelatihan sablon yang diberikan berupa sablon manual dengan pasta rubber. Tempat pelaksanaan pelatihan dilakukan di Jalan Gebras, tepatnya di posko milik karang taruna yang berdekatan dengan rumah ketua RT ibu Tety Juhriah, pada tanggal 15 April 2018. Narasumber pelatihan ini dilakukan oleh mahasiswa UHAMKA sejumlah 2 orang. 
Pelaksanaan IbM (Ipteks bagi Masyarakat) sudah dilaksanakan sebanyak lima tahapan yang sudah direncanakan. Tahapan pelatihan yang sudah dilaksanakan dapat dibagi dalam beberapa materi sebagai berikut ini.

\section{Tahap Pengenalan Teknik Sablon Konveksi Secara Umum}

Dalam tahapan ini hasil yang dicapai bahwa peserta pelatihan mendapat materi pengetahuan mengenai seputar teknik sablon secara umum, baik sejarah teknik sablon, istilah dan teknik yang berhubungan dengan sablon, prospek dan potensi dari ketrampilan sablon bagi pengembangan kewirausahaan Selain itu mendengarkan uraian dari nara sumber, peserta pelatihan diberi kesempatan untukbelajar secara langsung mengenai langkah membuat sablon yang baik sehingga hasil yang diperoleh dari praktek sablon tersebut siap untuk dijual di pasaran.

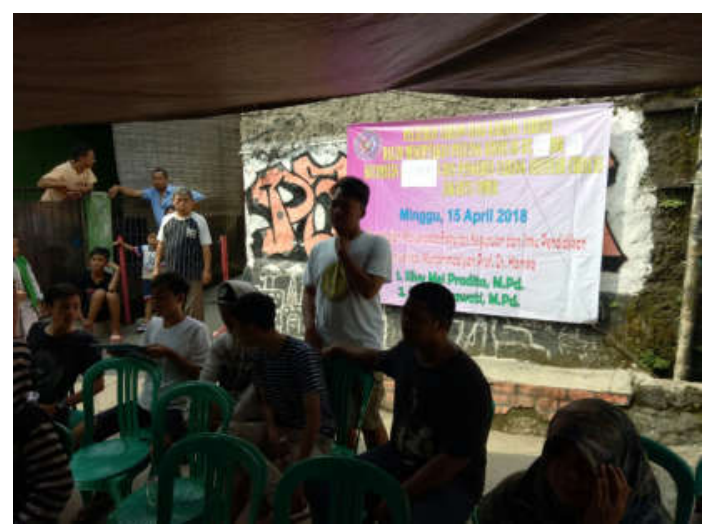

Gambar 1. Pengenalan Teknik Sablon Secara Umum

Dengan konsep learning by doing (belajar sambil mempraktekkan), pengetahuan dan ketrampilan mengenai hal tersebut dan akan memperoleh hasil yang optimal dan memuaskan serta peserta akan langsung mengenal dan mengetahui apa saja materi yang ditanyakan oleh peserta ataupun hal yang perlu dijelaskan lebih rinci dari materi pelatihan.

Media tayangan audiovisual lebih diminati dikarenakan lebih menarik dan para peserta dapat melihat langsung materi dengan berulang-ulang mengenai ketrampilan sablon. Materi tersebut didapat dari mengunggah dari internet.

Adapun kriteria keberhasilan peserta setelah mengikuti kegiatan ini dapat dilihat dari pemahaman dan kemampuan/keterampilan para peserta terhadap langkah-langkah/ tata cara dalam menyablon kaos, sehingga dapat diterapkan dalam kehidupannya.

\section{Tahap Pengenalan Peralatan dan Bahan Sablon (Cetak Saring)}

Dalam tahapan ini hasil yang dicapai dengan materi yang lebih detil mengenai peralatan dan bahan sablon, dimana peserta mengetahui fungsi dan kegunaan baik 
peralatan utama maupun peralatan pembantu teknik sablon, sedankan materi bahan sablon, berupa bahan pewarna (cat) dan cairan kimia lainnya sebagai bahan pendukung teknik sablon.

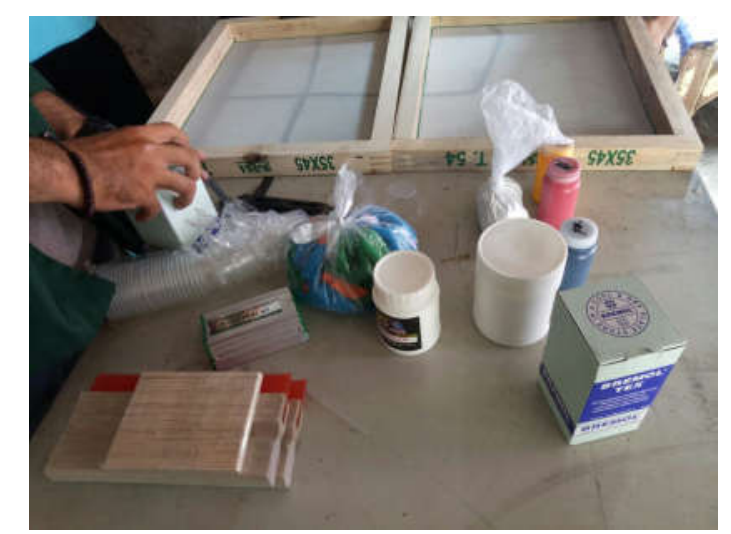

Gambar 2. Pengenalan Peralatan, Bahan, dan Teknik Sablon

Peserta bisa mengetahui akan manfaat dan cara pengoperasian peralatan dan bahan yang digunakan dalam ketrampilan tersebut, baik melalui tangan persentasi, modul yang diberikan dan demostrasi secara langsung. Metode demontrasi tetap dominan dalam tahapan ini dikarenakan adanya praktek secara langsung terhadap peserta pelatihan.

\section{Pembuatan Desain}

Pada tahapan ini akan direncanakan pemberian materi sekitar pembuatan desain gambar yang akan dicetak/disablon pada kaos. Desain yang dibuat akan dibantu dengan contoh-contoh desain sederhana sehingga peserta akan lebih mudah menerima materi tersebut.

Pada saat kegiatan pembuatan desain yaitu dengan membagi peserta ke dalam tiga kelompok untuk mempraktikan secara langsung tata cara menyablon, saat itu pula diikuti dan dipraktekan oleh para pemuda karang taruna dan ibu Aisyiyah cabang Ciracas. Adapun tahap pertama yaitu narasumber memberikan gambaran bagaimana cara mengoleskan emulsi film pada permukaan screen (dengan menggunakan spatula atau sendok plastik yang tipis untuk meratakan emulsi film ke seluruh permukaan screen). 


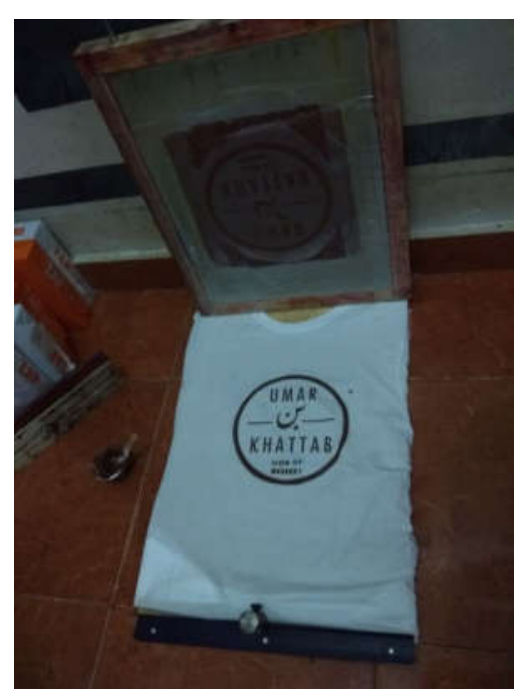

Gambar 3. Contoh Gambar Desain Sablon Tulisan

\section{Tahapan Mengafdruk (Pemindahan Gambar ke Screen)}

Tahapan ini akan memberi pengetahuan dan ketrampilan mengenai proses mengafdruk atau pemindahan gambar/desain ke dalam screen yang sudah disiapkan dengan metode penyinaran dengan cahaya buatan (lampu neon \listrik) atau dengan sinar matahari. Tahapan ini menjadi kegiatan yang sangat penting dalam rangkaian kegiatan sablon sebab dari hasil tahapan ini akan terlihat bahwa sablon nantinya akan menempel pada kain/kaos nantinya.

Kemudian narasumber melakukan print gambar desain yang akan disablon dan meletakkan pada screen yang telah diolesi emulsi film dan telah kering. Langkah selanjutnya, narasumber memberikan contoh bagaimana cara menimpa kertas desain yang menempel pada screen dengan busa dan pemberat yang rata, lalu menutup screen, busa dan pemberat dengan plastik sampah warna hitam. Setelah itu menyalakan lampu UV atau lampu neon dan biarkan menyala sekitar 10 menit.

Kegiatan selanjutnya, mempraktikan cara mencuci screen yang telah dipanasi dengan hati-hati, mengunci screen dan meletakkan kaos pada meja sablon, lalu menurunkan screen dan mengeluarkan pasta rubber ke screen sepanjang desain yang akan dicetak. Mengaduk dan mempadatkan rubber diatas screen sepanjang desain, sampai akhirnya kaos telah siap dipakai. Kegiatan mempraktekan ini diselingi juga dengan tanya jawab dari para peserta. Seluruh peserta terlihat sangat antusias mengikuti pelatihan menyablon ini. 

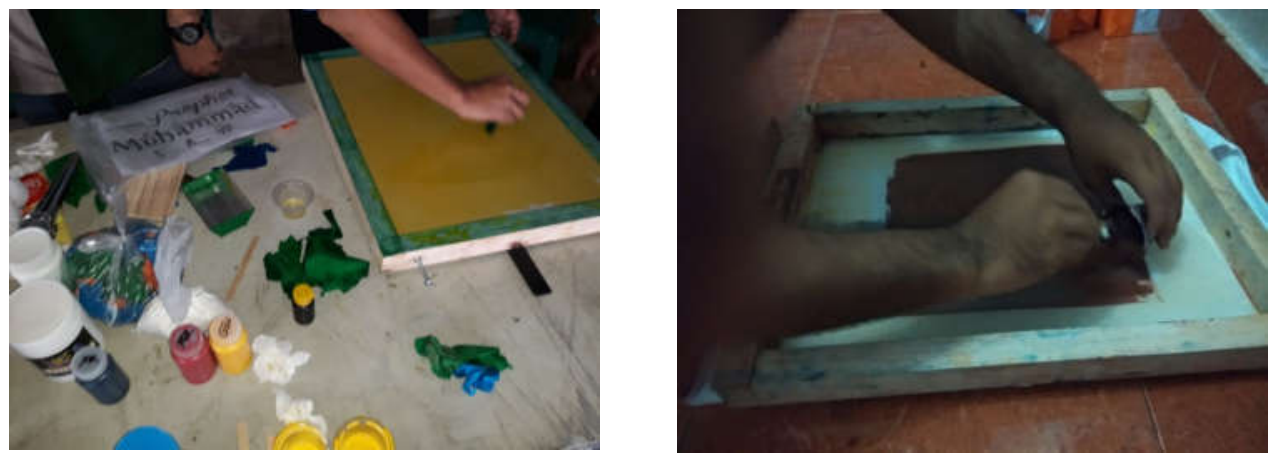

Gambar 4. Proses Mengafdruk Pada Screen Sablon

\section{Proses Penyablonan pada Bahan Kaos}

Proses pada tahapan ini akan menentukan dari semua tahapan pendahuluan yang sudah dilaksanakan didepan. Tahapan ini semua peserta akan mencoba dan praktek langsung bagaimana proses penyablonan melalui alat yang disebut rakel dan screen sudah diberi cat pewarna. Praktek langsung diharapkan peserta akan langsung merasakan dan mengetahui proses tersebut.
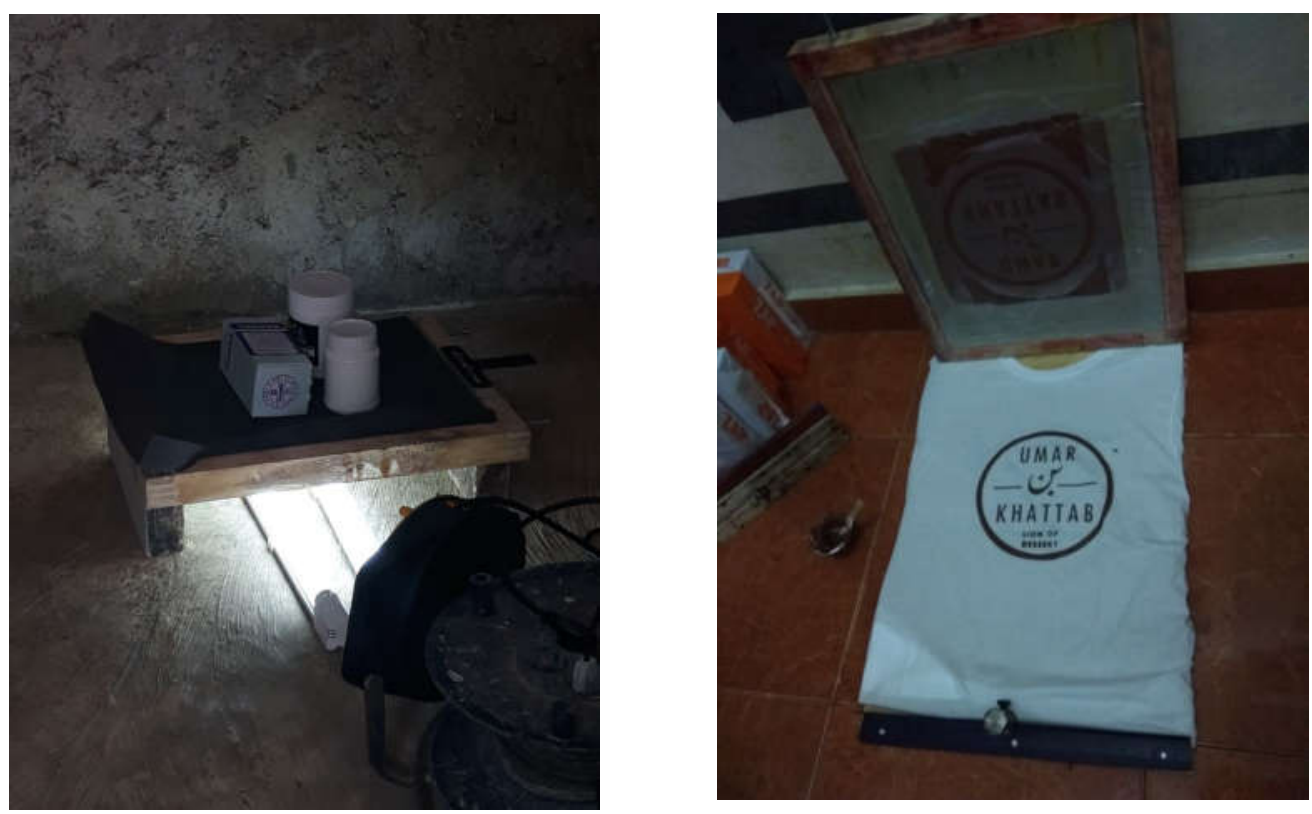

Gambar 5. Proses Sablon Pada Bahan T-Shirt

\section{KESIMPULAN}

Kesimpulan yang bisa diambil dari proses pelatihan ini adalah: 1) pelatihan sablon berisi materi teknologi tepat guna menjadi wahana yang sangat dibutuhkan masyarakat umum, khususnya pemuda karang taruna sebagai bekal untuk membuka wawasan workshop dan latihan kewirausahaan dan latihan membuat kreativitas sablon bagi pemuda karang taruna, 2) diperlukan koordinasi antara stakeholder yang berkompeten baik antara 
masyarakat, pemerintah maupun akademisi dalam memberi ketrampilan yang sejenis yang bermanfaat ke depannya agar membuka keterampilan berwirausaha bagi pemuda karang taruna.

Saran yang bisa disampaikan dalam pelaksanaan pelatihan sablon yang digunakan untuk lebih menyempurnakan program tersebut ke depannya serta dapat memberi wacana pengembangan untuk pelatihan yang lain. Saran-saran yang bisa disampaikan, antara lain: 1) penyebarluasan materi pelatihan sablon bagi masyarakat yang membutuhkan akan informasi teknologi tepat guna, 2) aspek keberlanjutan dalam program pelatihan ini sangat diperlukan agar dapat menerapkan ketrampilan tersebut, baik melalui lembaga pemerintah yang terkait dengan hal tersebut.

\section{UCAPAN TERIMA KASIH}

Terimakasih kepada Ketua Karang taruna Rt. 011 Rw. 005 Kecamatan Ciracas dan Ketua Pengurus cabang aisyiyah Ciracas, Jakarta Timur.

\section{DAFTAR PUSTAKA}

Agustina, C., \& Sularto, L. (2011). Intensi kewirausahaan mahasiswa (Studi perbandingan antara fakultas ekonomi dan fakultas ilmu komputer). Proceeding PESAT (Psikologi, Ekonomi, Sastra, Arsitektur, \& Sipil) Universitas Gunadarma, Depok, 18-19 Oktober 2011, 4: hal. 6369.

Hendrariningrum, R. \& Susilo, M. E. (2008). Fashion Gaya Hidup: Identitas dan Komunikasi. Jurnal Ilmu Komunikasi, vol. 6 (2), 25-32.

Lestari, S. B. (2014). Fashion sebagai Komunikasi Identitas Sosial di Kalangan Mahasiswa. Ragam Jurnal Pengembangan Humaniora, vol. 14 (3), 225-238.

Sarangih, R. (2017). A Membangun Usaha Kreatif, Inovatif dan Bermanfaat Melalui Penerapan Kewirausahaan Sosial. Jurnal Kewirausahaan, vol. 3 (2), 26-34.

Sumardi, K. (2007). Menakar Jiwa Wirausaha Mahasiswa Teknik Mesin Angkatan 2005. Jurnal Pendidikan Teknologi Kejuruan, vol. 4 (10).

Sulastri, Budhi Akbar, Luthpi Safahi, Susilo S. (2018). Pengaruh Strategi Pembelajaran Critical Incident terhadap Keterampilan Analisis Siswa. Assimilation. Vol. 1(2): 7781.

Trisnawati, T. Y. (2011). Fashion sebagai Bentuk Ekspresi Diri Dalam Komunikasi. The Messenger, vol. 3(1), 36-47.

(C) 2018 Oleh authors. Lisensi Jurnal Solma, LPPM-UHAMKA, Jakarta. Artikel ini bersifat open access yang didistribusikan di bawah syarat dan ketentuan Creative Commons Attribution (CC BY) license (http://creativecommons.org/licenses/by/4.0/). 